Article

\title{
Paradoxes of the Italian Historic Centres between Underutilisation and Planning Policies for Sustainability
}

\author{
Paola Pellegrini ${ }^{1, *}$ and Ezio Micelli ${ }^{2}$ (I) \\ 1 Department of Urban Planning and Design, Xi'an Jiaotong-Liverpool University, Suzhou 215123, China \\ 2 Department of Architecture and Arts, Università IUAV di Venezia, 30123 Venice, Italy; micelli@iuav.it \\ * Correspondence: paola.pellegrini@xjtlu.edu.cn; Tel.: +86-512-8188-4774
}

Received: 9 March 2019; Accepted: 16 April 2019; Published: 7 May 2019

\begin{abstract}
The paper presents the analysis of the statistical data on population and real estate in 20 small-to-medium-sized cities in Northern Italy and shows a high rate of vacancy of housing and significant shrinkage of businesses and institutions in the historic centres, where urban heritage is concentrated. Given these findings, the paper analyses the official city plans of the cities with the worst underutilisation conditions, to understand how the plans have reacted to the decline of the centre. The result shows the extensive planning and regulation activity has very limitedly registered the phenomenon and failed to propose the empty inner cores as resources to reduce land consumption and recycle valuable assets in a circular economic vision. Combining the statistical data and the findings from the city plans, the paper concludes that Italian historic centres are living paradoxes-a collection of beauty, icon of well-being, model of sustainability, but abandoned-and therefore, the dense regulatory mechanisms that were necessary to conserve urban heritage during the decades of economic and demographic growth must be reframed to implement a circular economy and adapt to new requirements for living conditions.
\end{abstract}

Keywords: urban heritage; historic centre; regulation; sustainability; city plan

\section{Introduction and Research Method}

Historic centres are the identity and heritage of Italian cities and have for decades been at the centre of cultural debate and administrative action, leading to extensive regulation activities and planning documents to conserve and restore them [1-9]. However, the interpretation of demographic movements and dynamics of uses over the past 30 years suggest that the effects of the planning policies and regulations on the settlement choices should be questioned because the internationally recognized heritage of the centres, one of the most valuable assets in urban Italy, is underutilized and therefore, devitalized and wasted. The issue of the underutilisation of the historic centres has not been studied in detail considering the long time span yet, even though the survey of the Associazione Nazionale Centri Storici Artistici has greatly contributed [10], its relation with plans and regulations have not been analysed; some literature deals with the problem of the regeneration of the historic centres [11-14], but none deals specifically with the reaction of planning instruments to underutilisation and little public discussion debates it. The research presented tries to fill this void and is the second phase of an on-going investigation.

The first phase of the research analyzed the Census data of 1991-2011 of demographic movements and property dynamics of 14 small-to-medium-sized cities in Northern Italy [15,16]. The findings show severe underutilisation in the city centres and urge to question the effectiveness of the planning approach and regulations. The research method of the second phase involved the following steps: 
- We increased the number of cities we investigated to 20 in order to cover the whole of Northern Italy; the same phenomena found in the first 14 cases were found also in the six new ones.

- Selection of the cities to further analyze according to the findings: The cities with the worst condition of vacancy were selected because the phenomenon in these cities is so evident that local planning activity should have tried to deal with the issue; the paper claims the city plans are not the main factor which caused the vacancy, but a mix of socio-economic causes. Therefore, the paper explores how planning activity reacts to the phenomenon where it is most observable.

- Collection of the city plans available in the official web page of the municipalities: The general planning documents and those specifically related to heritage conservation (if any) were collected.

- Analysis of the texts and maps of the plans, both in the descriptive parts (focusing on which phenomena are impacting the city according to the documents and if underutilisation is recorded among them) and in the design part (focusing on what development is proposed, what importance is given to sustainability, which actions are defined for the city centre and what role it is given in the future of the city). The selected cities are in different regions, and every region in Italy has a city planning law. Therefore, the planning processes are slightly different and the documents cannot be directly compared.

- Assessment of the conceptual and practical link between the phenomena of underutilisation and the choices of the plans for sustainability, that is to say if and how the "empty" built heritage in historic city centres is given a role to support the sustainable development of cities in the perspective of a circular economy and according to the International Charters and debate about urban development, which widely promote the connection of built urban heritage and sustainability [17-19].

- Conclusions, both expressed as paradoxes and challenges.

The structure of the paper is as follows: The second paragraph presents the results of the quantitative research about the underutilisation of the building stocks in the historic centres of small-to-medium-sized cities in Northern Italy between 1991 and 2011; the third paragraph presents the results of the qualitative research regarding the planning instruments, which define the future development of the city. The fourth paragraph introduces some paradoxes of the historic city centres, that is to say, the essential characters which should determine the value of the historic core, but fail to do so; these paradoxes should be the starting point for the re-framing of the cultural approach and the policies for the urban heritage, which is proposed in the last paragraph.

Cases of gradual decline over the last 20 years of the historic city centres in small-to-medium-sized cities can be found in the whole of Europe: Shrinkage in population, underutilized stock and diminished importance as places of exchange and congregation are widespread phenomena [20-24]. This paper wants to contribute to the academic and professional debate about this decline presenting the North Italian case, which is relevant because of the great value of its urban heritage, the extensive protection measures applied since the 1960s and it is a place where even centres enlisted in the United Nations Educational, Scientific and Cultural Organization (UNESCO) world heritage are underutilized.

\section{Evidence of Underutilisation of the Built Stock in Historic Centres of Small-to-Medium-Sized Cities in Northern Italy}

The research analyzed the Italian Census data from 1991 to 2011, the last comprehensive available one, of 20 small-to-medium-sized cities in six regions of Northern Italy: Friuli Venezia Giulia, Veneto, Trentino Alto Adige, Emilia Romagna, Lombardia, Piemonte $[15,16]$. There is no official classification in Italy of what a small-to-medium-sized city is; the research adopted the range between 30,000 and 200,000 inhabitants, which is pertinent to the dimension of the urban centres in Italy [25-27].

The analyzed cities are Udine, Pordenone, Treviso, Vicenza, Conegliano, Bassano del Grappa, Ravenna, Ferrara, Parma, Modena, Brescia, Mantua, Cremona, Bergamo, Pavia, Trento, Rovereto, Novara, Alba, Alessandria. All their city centres conserve a built heritage of exceptional value, some of them-Vicenza, Mantua, Ferrara-are listed as historic centres in the UNESCO World Heritage 
Sites, while some others-Modena, Pavia, Ravenna-have monuments included in the same list. The analyzed cities are a very relevant sample of the urban world of Northern Italy and host almost two million people of whom almost 10\% lived in the historic centres in 2011, see Figure 1, Table 1).

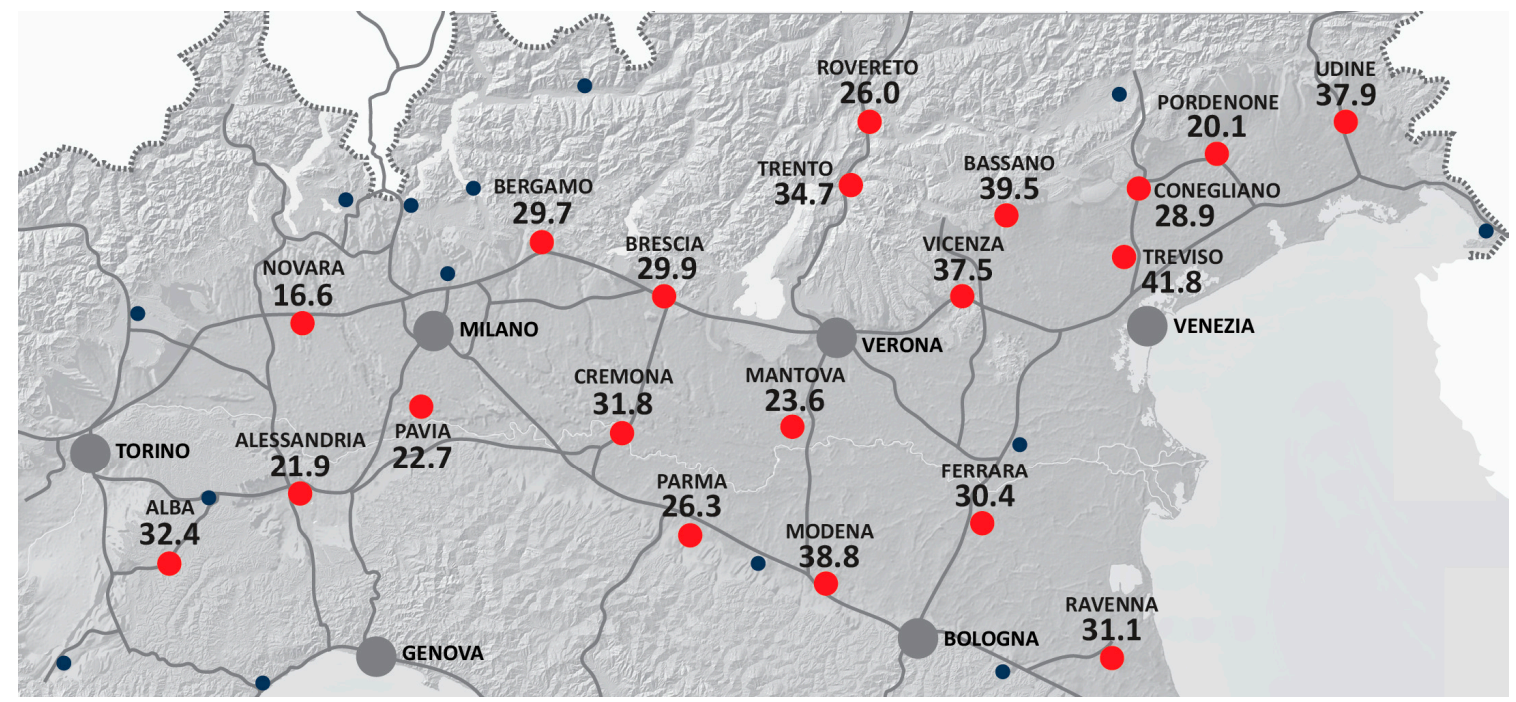

Figure 1. The 20 cities in Northern Italy; the numbers are the percentage of housing units not occupied in the ZTL.

The municipal territory of every city was divided into three areas to obtain specific results and compare dynamics: The inner part of the historic centre identified as the controlled traffic zone (ZTL), the rest of the historic centre defined by the last defensive walls and the rest of the municipality.

The analysis shows unoccupied housing (labelled "abitazioni vuote" by the Census) in the entire historic centre increased on average from $16 \%$ to $26 \%$ and systematically exceeded the other urban areas where the share of the unoccupied stock increased from $9 \%$ to $14.2 \%$. The situation is even more significant in the ZTL: In these areas, the percentage of unoccupied housing increased from $18.8 \%$ to $30 \%$.

The vacancy rate in ZTL increases significantly in some cities, such as Udine, Treviso and Modena when compared to the rate of the other historic centres; in Treviso, for example, from 1991 to 2011, the percentage of unoccupied housing reached $41.8 \%$, whereas it was $21.4 \%$ twenty years previously. The vacancy does not appear to be related to specific parts of the historic centre but appears to be a widespread process; in fact, in the majority of the centres it does not involve buildings in their entirety and this partial utilisation mitigates the perception of the phenomenon.

The vacancy rate, moreover, does not relate to the degradation of built stock nor is the decline of the population due to neglect: The large majority of buildings in northern Italian city centres, especially those whose heritage is particularly valuable, were largely restored and renovated in the 1980s and 1990s, as were the large majority of public open spaces; therefore, they are an available stock in acceptable conditions.

The value of these empty units has an absolute economic significance; in fact, the sum is 33,775 units out of a total of 130,084 in 2011, with an increase of 17,642 units since 1991. If this empty stock is assigned an under-estimated value of 1000 euros/sqm and an average surface of $100 \mathrm{~m} 2$ - the average size resulting from the analysis the Census Data for the 20 city centres-it sums up to a value of 3.37 billion euros, $0.2 \%$ of the Italian GDP in 2011. 
Table 1. Synoptic table of some results from the Census data analysis.

\begin{tabular}{|c|c|c|c|c|c|c|c|c|c|c|c|c|c|}
\hline City & Region & $\begin{array}{l}\text { Population } \\
\text { Outside the } \\
\text { Center, } 2011\end{array}$ & $\begin{array}{c}\text { Population } \\
\text { Variation } \\
\text { 1991-2011 } \\
\text { Outside the } \\
\text { Center (\%) }\end{array}$ & $\begin{array}{l}\text { Population } \\
\text { Variation } \\
\text { 1991-2011 in } \\
\text { the ZTL (\%) }\end{array}$ & $\begin{array}{c}\text { Population } \\
\text { Variation } \\
1991-2011 \text { in } \\
\text { the Historic } \\
\text { Center (\%) }\end{array}$ & $\begin{array}{l}\text { Unoccupied } \\
\text { Units Outside } \\
\text { the Center, } \\
2011(\%)\end{array}$ & $\begin{array}{l}\text { Unoccupied } \\
\text { Units Outside } \\
\text { the Center, } \\
1991(\%)\end{array}$ & $\begin{array}{l}\text { Unoccupied } \\
\text { Units in the } \\
\text { ZTL, } 2011(\%)\end{array}$ & $\begin{array}{l}\text { Unoccupied } \\
\text { Units in the } \\
\text { ZTL, } 1991(\%)\end{array}$ & $\begin{array}{l}\text { Unoccupied } \\
\text { Units in the } \\
\text { Historic } \\
\text { Center, } 2011\end{array}$ & $\begin{array}{c}\text { Difference } \\
\text { 2011-1991 of } \\
\text { Unoccupied } \\
\text { Units Outside } \\
\text { the Center (\%) }\end{array}$ & $\begin{array}{c}\text { Difference } \\
\text { 2011-1991 of } \\
\text { Unoccupied } \\
\text { Units in the } \\
\text { ZTL (\%) }\end{array}$ & $\begin{array}{l}\text { Foreigners in } \\
\text { the Center on } \\
\text { the Total } \\
\text { Residents }(\%)\end{array}$ \\
\hline Udine & $\begin{array}{c}\text { Friuli Venezia } \\
\text { Giulia }\end{array}$ & 98,287 & 1.06 & -8.30 & -10.23 & 12.5 & 7.45 & 37.9 & 15.69 & 2127 & 5.05 & 22.21 & 16.42 \\
\hline Pordenone & $\begin{array}{l}\text { Friuli Venezia } \\
\text { Giulia }\end{array}$ & 50,542 & 0.79 & -3.87 & -3.87 & 13.1 & 8.22 & 20.1 & 22.66 & 115 & 4.88 & -2.56 & 9.61 \\
\hline Treviso & Veneto & 81,014 & -2.16 & -5.41 & -11.67 & 12.39 & 6.64 & 41.78 & 21.39 & 1344 & 5.75 & 20.39 & 8.48 \\
\hline Conegliano & Veneto & 34,428 & -3.18 & -0.71 & -2.92 & 15.33 & 8.79 & 28.87 & 20.17 & 203 & 6.54 & 8.7 & 13.09 \\
\hline Vicenza & Veneto & 111,500 & 4.76 & -2.11 & -4.57 & 15.27 & 7.51 & 37.46 & 23.17 & 2097 & 7.76 & 14.29 & 12.36 \\
\hline Bassano dG & Veneto & 43,011 & 4.98 & -2.22 & -2.22 & 18.15 & 9.47 & 39.5 & 17.38 & 743 & 8.68 & 22.12 & 10.25 \\
\hline Mantova & Lombardia & 46,649 & -12.36 & -11.29 & -11.58 & 12.05 & 4.69 & 23.58 & 13.7 & 2138 & 7.36 & 9.88 & 8.22 \\
\hline Brescia & Lombardia & 189,931 & -2.68 & 3.25 & 1.54 & 13.08 & 6.28 & 29.93 & 22.47 & 3013 & 6.8 & 7.46 & 24.41 \\
\hline Cremona & Lombardia & 69,589 & -2.87 & -11.02 & -13.66 & 15.85 & 5.82 & 31.82 & 11.8 & 3808 & 10.03 & 20.02 & 18.06 \\
\hline Bergamo & Lombardia & 115,349 & 0.76 & -21.27 & -21.27 & 13.07 & 9.63 & 29.68 & 20.78 & 463 & 3.44 & 8.9 & 4.19 \\
\hline Pavia & Lombardia & 68,280 & -10.54 & -11.79 & -14.57 & 8.52 & 10.35 & 22.69 & 25.14 & 1390 & -1.83 & -2.45 & 6.88 \\
\hline Trento & $\begin{array}{l}\text { Trentino Alto } \\
\text { Adige }\end{array}$ & 114,198 & 12.41 & 14.54 & 14.01 & 14.35 & 9.97 & 34.68 & 22.92 & 957 & 4.38 & 11.76 & 10.59 \\
\hline Rovereto & $\begin{array}{l}\text { Trentino Alto } \\
\text { Adige }\end{array}$ & 37,754 & 15.32 & 2.96 & 8.44 & 14.57 & 11.27 & 25.96 & 20.39 & 545 & 3.3 & 5.57 & 19.61 \\
\hline Ferrara & $\begin{array}{c}\text { Emilia } \\
\text { Romagna }\end{array}$ & 132,545 & 0.98 & -17.84 & -21.59 & 14.3 & 6.6 & 30.4 & 18.08 & 4560 & 7.7 & 12.32 & 8.55 \\
\hline Modena & $\begin{array}{c}\text { Emilia } \\
\text { Romagna }\end{array}$ & 179,149 & 1.31 & 0.98 & -0.22 & 16.22 & 8.89 & 38.81 & 23.28 & 3238 & 7.33 & 15.53 & 26.14 \\
\hline Ravenna & $\begin{array}{c}\text { Emilia } \\
\text { Romagna }\end{array}$ & 153,740 & 14.23 & 3.15 & -4.48 & 28.51 & 29.06 & 31.14 & 9.49 & 1297 & -0.55 & 21.65 & 12.19 \\
\hline Parma & $\begin{array}{c}\text { Emilia } \\
\text { Romagna }\end{array}$ & 175,895 & 5.35 & -9.17 & -11.02 & 12.69 & 7.82 & 26.33 & 17.55 & 3774 & 4.87 & 8.78 & 15.88 \\
\hline Alba & Piemonte & 30,804 & 6.13 & -5.64 & -5.17 & 13.9 & 7.12 & 32.38 & 14.86 & 481 & 6.78 & 17.52 & 12.98 \\
\hline Novara & Piemonte & 101,952 & 0.65 & 9.19 & 6.23 & 7.23 & 7.45 & 15.58 & 26.72 & 258 & -0.22 & -11.14 & 12.36 \\
\hline Alessandria & Piemonte & 89,411 & 0.52 & -13.64 & -10.25 & 13.13 & 7.19 & 21.87 & 8.71 & 1224 & 5.94 & 13.16 & 17.75 \\
\hline Average & & & 1.77 & -4.51 & -5.95 & 14.21 & 9.01 & 30.02 & 18.82 & & 5.20 & 11.21 & 13.40 \\
\hline Total & & $1,924,028$ & & & & & & & & 33,775 & & & \\
\hline
\end{tabular}

Notes: The cities selected for the analysis of the city plan are highlighted. 
In the 20 centres that were analyzed, the population is decreasing: -20.118 units since 1991, on average $-10.35 \%$, but exceeds $-20 \%$ in Ferrara and Bergamo. This decrease is not directly proportional to the percentage of housing vacancy, and is clearly less relevant; this difference may be related to the deaths of single elderly people who often live in the historic centres and the arrival of foreigners. In fact, despite being almost irrelevant at the beginning of the 1990s, in twenty years, foreign residents have become a significant percentage of the inhabitants of the oldest parts of the city-in Brescia, foreign residents exceed a $24 \%$ share of the population, in Modena this share reaches $26 \%$-with an increase of twenty times compared to the figures of the early 1990 s.

The abandonment concerns not only residential units but also companies and institutions. The results regarding the companies operating in the historic centres are not homogeneous among the 20 cases and, very often, companies have not decreased in number, but have been re-organized with a significant reduction in employees, decreased by between one-fourth and one-fifth when compared to 1991, with an average decrease of over twenty percentage points $(-20.1 \%)$.

The results regarding institutions in the historic centres are more clear-cut. The density of institutions in the historic centre-the units per hectare-continues to be higher than in the rest of the municipality, but has suffered a drastic shrinkage, decreasing between two-thirds and four-fifths compared to 1991. The variation in institutions is homogeneous and indifferent to the regional location and the total local units declined by more than $70 \%(-73.9 \%)$ in the twenty years considered. Similarly, the institutions' employees decreased in all cases, with an average reduction of one-third. The average decrease in the rest of the municipal territories is also important, but minor: $-58.3 \%$ for the local units. This diminution is partly due to the rationalization of office premises following mergers and partly due to relocation in more accessible areas of the city.

The interpretation of demographic movements and property dynamics of the last thirty years in 20 small-to-medium-sized cities in the whole of Northern Italy reveals severe underutilization; original inhabitants have been abandoning the centres, partially substituted by immigrants, enterprises are significantly reduced, and many institutions have opted for new locations. The choice of new locations by households, public institutions and businesses is exceptional as well as paradoxical because the abandonment involves parts of the city that have most benefited from the community's resources for centuries, constantly improving infrastructures and public spaces both in the quality of service and beauty.

\section{The Missed Opportunity of Promoting the Re-cycling of the City Centres in the City Planning Instruments}

Has the city planning activity considered the underutilisation of the cores? Has it considered it as a problem? The theme is central for the development of Italian cities in this period of urban reuse, when a circular economy and sustainability concepts should be considered. In fact, if the cities' agenda takes on a more rational use of the land through the careful selection of projects which consume land, in particular, affecting the primary sector where there is a concern about food production, and if the regeneration of properties through physical as well as social redevelopment is considered a priority, then the historic centre of Italian cities becomes a fundamental test of adapting a stock of primary cultural, economic and social value to contemporary needs and wishes.

Even though precise numbers for a large sample of cities had not been produced until very recently $[10,15,16]$, the abandonment of the historic centre has been perceivable for several years in Italy. Therefore, it is plausible to hypothesize city planning documents have registered it and proposed to recycle the empty stock, adopting a circular economy approach, which integrates sustainable production as well as better use of resources. To understand the reaction to the phenomenon, the research explored the city planning documents of the cities with the worst condition of not-occupied units in the most valuable part of the city, the ZTLs. The paper claims the city plans are not the main factor which caused the underutilisation, but that it was a mixture of socio-economic causes, see paragraph 4.4 and Conclusions. Therefore, the paper explores how planning activity reacts to the phenomenon where it 
is most observable. The selected cases are Treviso, Modena, Udine, Vicenza where, in 2011, the empty units in ZTL reached $41.8 \%, 38.8 \%, 37.9 \%, 37.5 \%$ of the total units, respectively, see Table 1 .

The documents are available online in the official webpages of the municipalities. The research analyzed if and how the city planning documents react to the underutilisation phenomena, see Table 2:

- if the underutilization is reported;

- if sustainability is among the goals of the city;

- if the built heritage in the centre is considered an asset to exploit and reduce the consumption of land, establishing in this way a direct link between the phenomena and an efficient and sustainable use of resources;

- if innovative rules are established to both facilitate the regeneration process and conserve the heritage;

- if new developments and land consumption are planned.

Table 2. Table comparing the city plans.

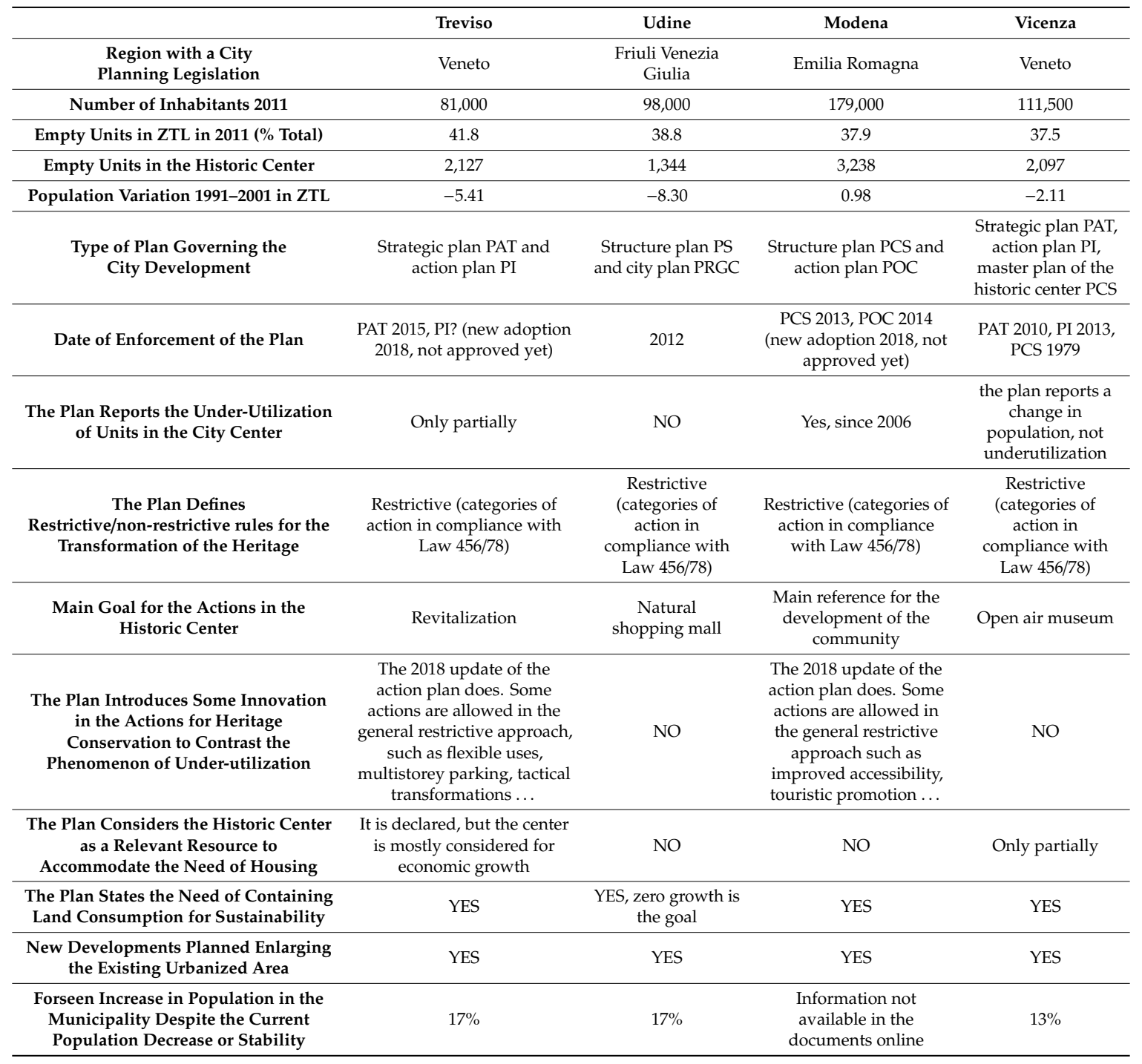

The reading focused on some key terms: Underutilization, heritage, centre, conservation, sustainability, sustainable development.

The research analyzed the spatial planning documents because they are the manifesto of the public and the official position assumed by the local governments in recent years: The research produced an 
exegesis of the texts and maps which compose the city plans as a critical assessment able to decipher urban planning stories and their coherence with the current reality.

The analysis shows the planning documents in force only recently started to acknowledge the problem and only a few policies were proposed to actively revitalize the centre. The research assumes it as evidence that the concept, tools and procedures of planning and regulatory practice-matured over the course of decades of economic and demographic growth-should be updated to be able to react to the structural changes in Italian society and economics and to the new-however, not really new-urban dynamics and mega-trends.

\subsection{City of Treviso, Acknowledgement of the Phenomenon in the Bigger Picture but Late and Limited Action}

Treviso, Veneto Region, has 81,000 inhabitants and 1600 inhabitants in the 24 ha of the ZTL in the the heart of the city centre [25]. Treviso has a strategic plan, approved in 2015 (Piano di Assetto del Territorio-PAT) and an action plan, adopted in 2018 (Piano degli Interventi-PI) [28,29].

PAT registers some cases of underutilized or unutilized building stock, but does not acknowledge the phenomena of abandonment of the historic centre, which was already evident when the drafting of the plan started. The document which defines how much the city can grow in relation to what already exists classifies only the un-let units as the unutilized stock, assessing it to be $8.5 \%$ of the total availability, and declares it is non-recoverable and, therefore, not relevant to answer the present and future demand $[30,31]$.

Despite the general goals stated-intensified requalification of the existing stock and historic and cultural identities as strategic assets for economic growth-and despite the population decrease by $2.16 \%$ in the municipality and by $11 \%$ in the city centre between 1991 and 2011, PAT foresees an increase in population of 14,500 units, almost $17 \%$ of the existing population, and urbanizes new areas to accommodate this increase.

In the strategic actions for sustainable urban regeneration (ambiti dei programmi complessi) the historic centre is not included, even though its requalification would require minor urbanization investments compared to the targeted abandoned large areas, twentieth-century complexes in peripheral areas that no longer respond to any use; these are very evident to the inhabitants and represent a problem for the local governments, while the centre clearly does not.

More attention to the city centre is given in the action plan-PI adopted in 2018, see Figure 2. It claims the need for actions for containing land consumption and revitalizing the city centre, allowing more flexible uses, multistory parking in dismissed structures, public-private use of parking. PI almost halves the amount of new residential developments and pursues the return of inhabitants to within the perimeter of the historic centre, and in considering the centre as an asset, PI also mentions the tool for temporary reuse introduced by the regional legislation for the containment of land consumption: To activate a process of regeneration of the abandoned or unused building stock with tactical interventions, waiting for a more substantial and definitive restructuring operation [32,33]. PI is a step forward because it clearly identifies the problems associated with the city centre. However, this action is late and limited considering the significance of the issue.

\subsection{City of Udine, neither Acknowledgement nor Action}

Udine, Friuli Venezia Giulia Region, has 98,000 inhabitants and 1700 inhabitants in the 38 ha restricted traffic zone [25]. The city planning documents approved in 2012 (Piano Strutturale-PS and Piano Regolatore Generale Comunale-PRGC) do not acknowledge the abandonment of the city centre and, therefore, do not give it a role in the actions for future sustainable development; generally, the plans give a representation of a city without severe problems [34].

Considering the slow demographic trends, PRGC reasonably defines the population in 2025 as 101,666 inhabitants and defines the normal un-let units in the city at $8.8 \%$. Nevertheless, to answer the diverse housing needs, the plan adds 12,270 units to the existing ones, corresponding to a total 
population of 117,050 inhabitants $(+17 \%)$. To answer this future demand, the Piano Regolatore Generale Comunale does not specifically plan the requalification of the stock in the centre [35,36].

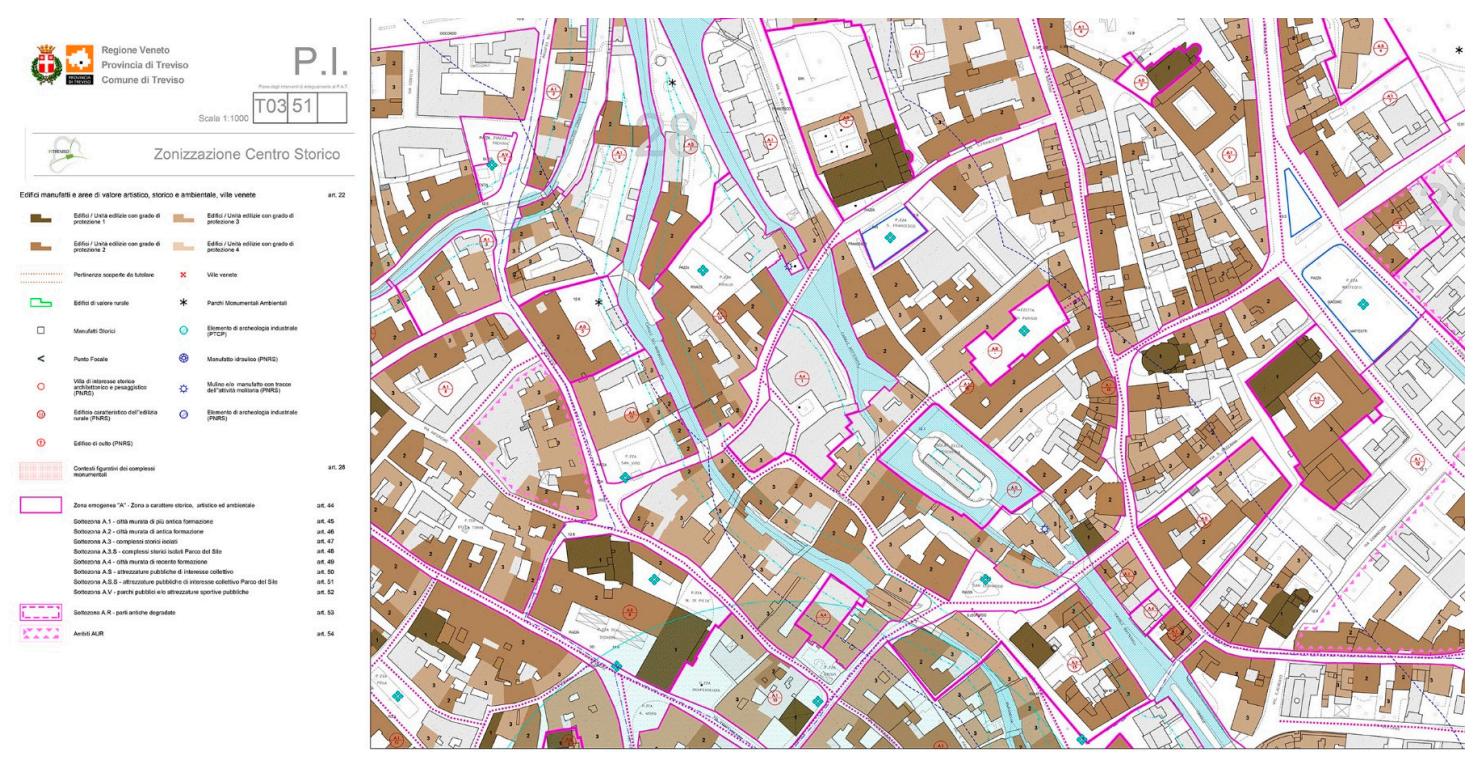

Figure 2. Excerpt from the Piano degli Interventi-PI of the city of Treviso, 2018; zoning and regulations of the historic centre.

PRGC mentions the goal of enhancing livability and re-qualifying the most valuable heritage to increase its attractiveness, but proposes some remarks that are unconnected to specific actions. The main idea, which shows some worries about the centre, is to consider the centre as a "natural shopping mall" in order to compete with the extremely successful shopping malls in the periphery, which have been massively draining customers and visitors since the 1990s. This idea proposes to reinforce the core without exploiting its identity, but adopting a model produced for different urban contexts. For this goal, PRGC proposes to enhance the public open spaces for pedestrians, mostly with projects of connections in the centre itself. This strategy seems to be out of focus, as the historic centre of Udine was designed and has always been a place for pedestrians and these connections are already there; in contradiction to this direction, the new local government in 2018 has approved to reintroduce car traffic in the ZTL.

The structural plan confirms the traditional interpretation of the territory around the Udine as a polycentric structure where the city is the most relevant core for its history and extraordinary urban quality; the plan also confirms Udine's historic centre as the centre of this territory, when in reality, it is in a crisis of representation and vitality with a rate of $39 \%$ of underutilized housing units in 2011, a $70 \%$ reduction in local units of public institutions, and an $8.30 \%$ decrease in inhabitants.

\subsection{City of Modena, Early Acknowledgement of the Phenomenon and Recent Attempt to Promote Actions}

Modena, Emilia Romagna Region, has 179,000 inhabitants and 8900 inhabitants in the 72 ha restricted traffic zone [25]. The structural plan, approved in 2013 (Piano Strutturale Comunale-PSC), reacts to the underutilisation phenomena impacting the historic centre, a problem studied since $2006[37,38]$.

PSC describes the constant transformation of the centre and focuses on two groups of actions, the first related to accessibility, rest areas, garages-declared as very relevant-and the second, to re-generation. For the first, the plan refers to further studies. For the second, it proposes to promote cultural and recreational activities, as well as commercial ones, and also refers to further studies for understanding the residents' needs. The plan connects the requalification of some areas with reduced land consumption, referring to further specific policies [39]. 
The action plan approved in 2014 (Piano Operativo Comunale-POC and the related Regolamento Urbanistico Edilizio-RUE) fails to go one step further, that is to say, it neither specifies actions nor adds studies but adopts the usual and well-established practice for conservation: Almost every building in the city centre is subject to restrictive regulations (i.e., the Italian law defining the types of intervention: law 456/1978, art. 31), see Figure 3. In addition to these usual restrictions of transformation, increasing the dimensions of the buildings is always prohibited, as well as the change in use from shops, bars and laboratories into garages [40].
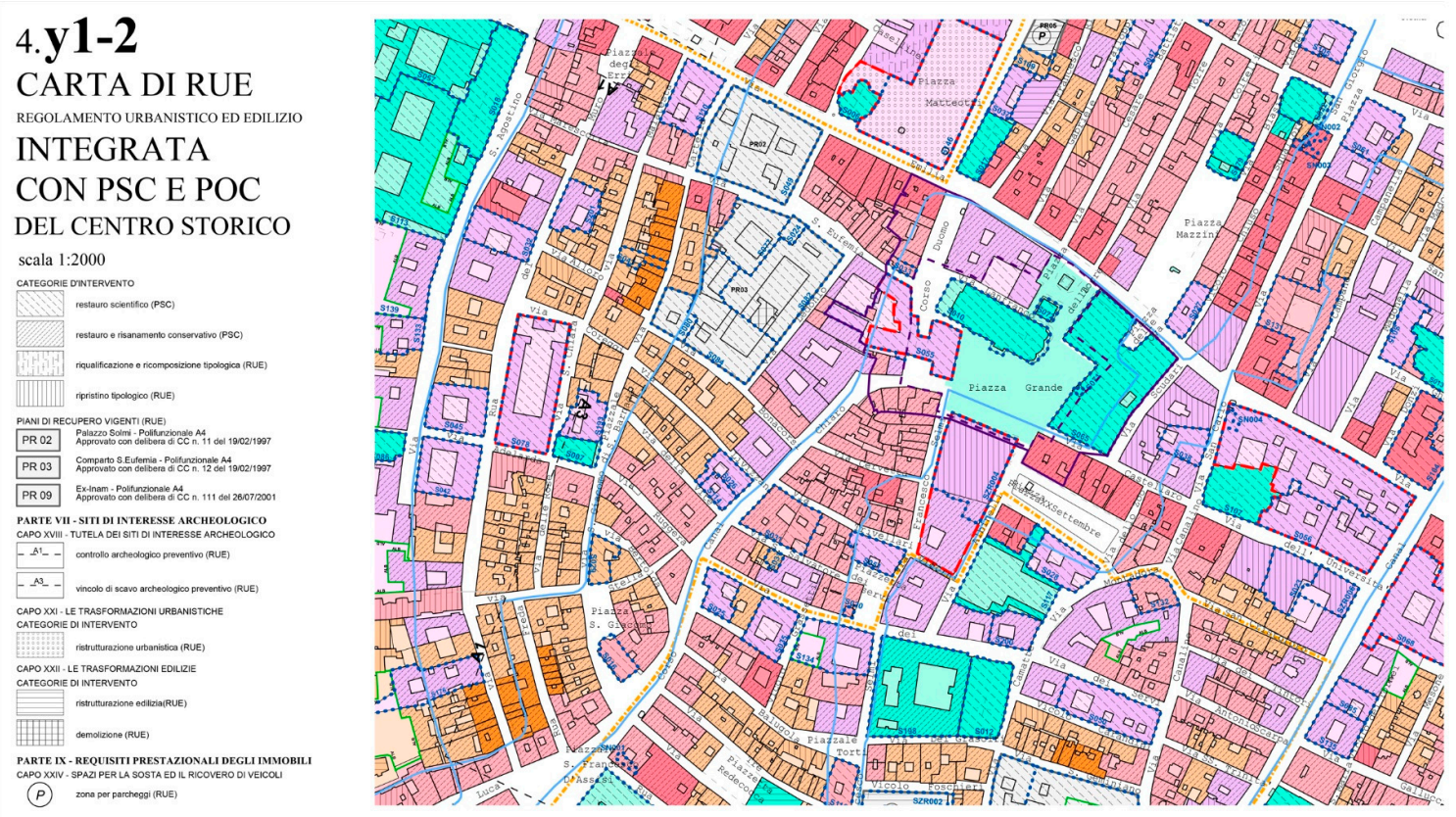

Figure 3. Excerpt from the Regolamento urbanistico edilizio-RUE of the city of Modena, 2013; zoning and regulations of the historic centre.

PSC gives a definition of the historic centre corresponding to the traditional idea of its values: The centre is a reference for the development of the local community, mostly for its public spaces and services which allow the inhabitants to be a community. According to this definition, the plan acts contradictorily: On one hand, it does not claim the recently diminished role, on the other, it includes the centre in the areas where public services are lacking, a new element to remark upon because the centre has traditionally been the place where services are concentrated.

Even if the plans in force do not propose an innovative approach to deal with the problems of the city centre, the revitalization of the historic centre with active policies has been discussed at a higher political level since the first months of 2018 and a new POC was adopted at the end of 2018: Facilities for the residents, improved accessibility and parking areas, economic support and touristic promotion are the solutions proposed.

\subsection{City of Vicenza, Some Acknowledgement and Some Action Limited in Purpose}

Vicenza, Veneto Region, has 111,500 inhabitants and 3019 inhabitants in the 50 ha restricted traffic zone [25]. The strategic city plan for Vicenza, approved in 2010 (Piano di Assetto del Territorio-PAT), declares a "crisis of identity" of the city centre for some of the reasons explained by the present research based on the interpretation of the Census Data: New, poor immigrants, weak public services, poor commercial supply and inadequate recreational areas [41,42]. To cope with this crisis, PAT suggests to improve cultural, recreational and shopping attractions and tourism and considers the city centre as an "open-air museum". The 'museumification' of the historic space is coherent with the age of the plan 
for the city centre in force (Piano particolareggiato per il Centro Storico-PCS), which dates back to 1979 (but was drafted in 1969, see Figure 4), even though it was partially updated in 1988 [43].

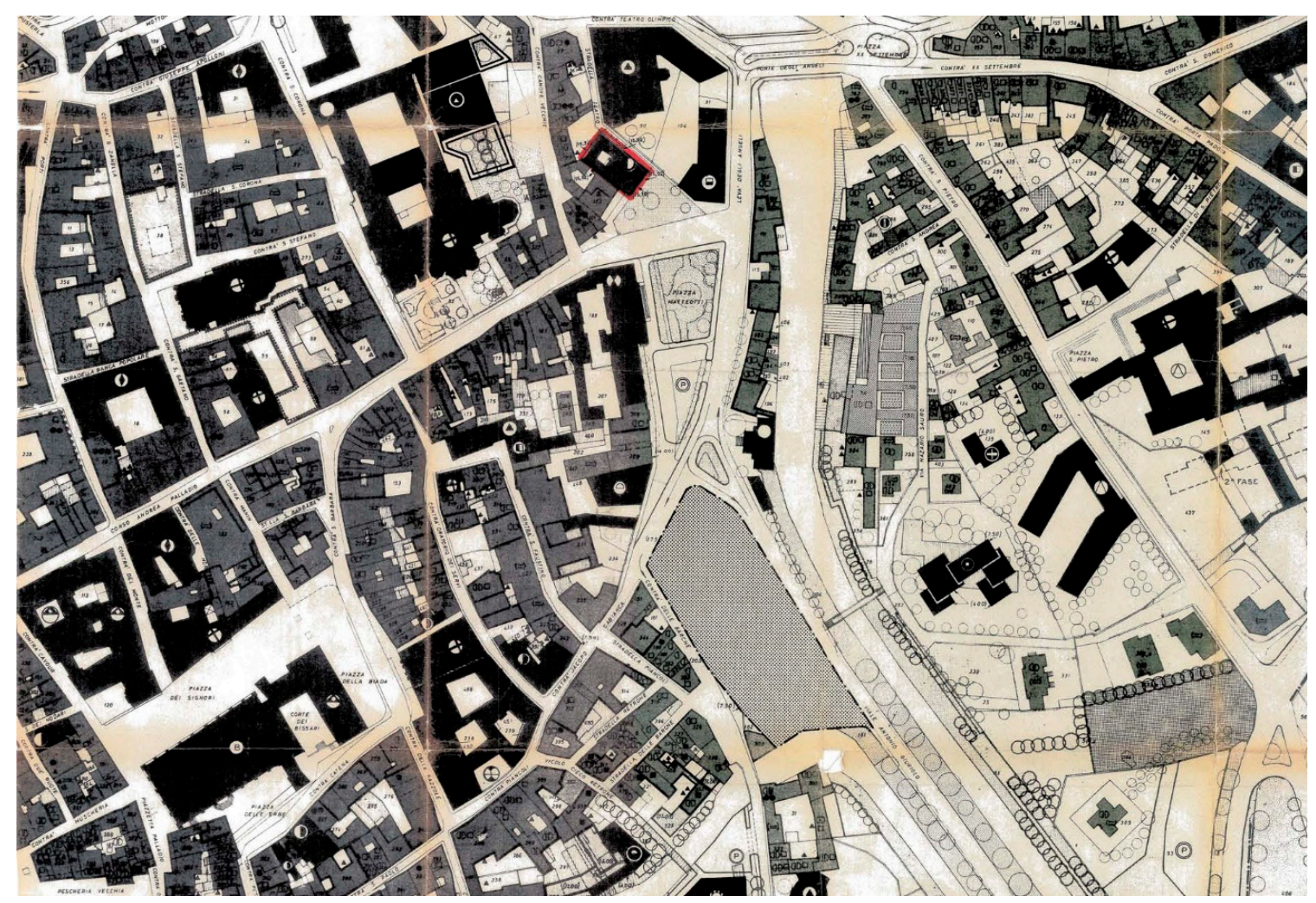

Figure 4. Excerpt from the Master plan of the city of Vicenza, 1969; zoning and regulations of the historic centre.

Similarly, PAT declares that the city centre must again become the place of high-quality residences, because the migrant and mobile population, that is increasingly occupying it, will cause its decay. PAT does not recognize in the new inhabitants a possible way to revitalize the centre, nor does it interpret the city centre as one of the "eco-neighbourhoods" which it defines their high-density and potential for regeneration: The main concern about the centre remains the conservation of its beauty and characteristics.

PAT promotes sustainability as a principle for a general urban re-structuring, and it stresses dwelling units must be obtained by re-using and re-qualifying the existing stock. However, the action plan approved in 2013 (Piano degli Interventi-PI) plans to accommodate only 600 of the future foreseen 14,269 new inhabitants in the city centre, while the present research found 2097 empty units potentially available [44].

Vicenza can be considered a paradigmatic example of the well-established approach to conservation in planning-resulting from an extensive technical, as well as conceptual theoretical reflection and definition of practices which goes back to the beginning of the XX century $[7,8,45,46]$ —consciously applied to deal with new conditions without updates or reframed regulations.

\subsection{Structural Difficulties and Conservational Approach}

Even though the numbers of vacancies are high and the value of the property not utilized seems to be of absolute economic significance, the city plans presented here fail to propose innovative policies to reuse the centre. A further step, i.e., to consider these actions as a way to reduce land consumption and recycle housing stocks, is only mentioned. 
The paper proposes that the examined plans express a structural difficulty in dealing with the historic centre within renewed cultural and economic coordinates. "Structural" means pertaining to the long-term cultural and organizational essence of the Italian regulation mechanism for protecting the heritage: In order to be in compliance with the law, regulations tend to deny transformation rather than to define an operational approach, allowing agreement and compensations.

Italian urbanism distinguishes between policies of regeneration based on cultural values-the building type, the permanence, the historical-architectural legacy-and actions based on scientific and technological values-sustainability, de-carbonisation, reduction of energy consumption, etc. This separation is highly inefficient, this is also because, in Italy, the conservational approach is often overwhelming due to the extension of the classification of heritage to essentially everything old $[47,48]$ and the idea that the historic centre—as a whole—is a work of art and, as such, it cannot be changed [49]. The risk of stagnation is increased by the lack of dialogue in Italy between the culture of design and the culture of conservation $[50,51]$.

\section{Four Paradoxes of the Italian Historic City Centres}

The results of the research show that some paradoxes exist in Italian historic centres. They are part of the most precious heritage of the country, locations of monuments and beauty, guarantee the cultural identity, icons of well-designed open spaces and well-being, and of a high-density and efficient use of land. Therefore, they should be successful but the interpretation of demographic movements and property dynamics over the past thirty years in small-to-medium-sized cities in Northern Italy reveal these positive and advantageous characteristics do not prevent the relocation of the population, businesses and institutions. The critical recognition of these paradoxes-presented in the following paragraphs-should be the starting point for the re-framing of the policies for urban heritage which do not seem able, as the previous paragraph shows, to give a dimension to the problems and react to transformation dynamics.

\subsection{High-density and Compactness}

The sustainability of high-density settlements has been a widely discussed topic together with the opportunity to drastically decrease land consumption for new settlements [52-55]. The historic centre has used land very efficiently because the settlement is compact and has a high-density: Generally, the centre is many times denser than the rest of the settlements in the municipality (in Udine, Brescia e Modena the inhabitants in the historic centre per square meter are roughly four times as many as in the rest of the city).

Compactness and high density produce also proximity to public services and can support public transportation, which is convenient and accessible because of the concentration of people and activities. It can be said the city centre has the required parameters to be sustainable because it is compact and of higher density, in a word, it has already the main characteristics of an "eco-neighborhood" [56]. But the issue is socio-cultural and related to changed desires for living condition: the heritage value and the human-scale value of the history centre are not enough to attract residents; failing to recognize it is misleading.

\subsection{Community Life and Local Identity}

The human-scale dimensions and the quality of the public spaces in the historic centre are generally praised and said to guarantee both individual well-being and community life in well-designed gathering places, as very influential scholars have been claiming for decades [57-59], reinforcing this myth in the Italian cities. These physical characters, where the symbols of the local community's identity are preserved, seem to reinforce the social bonds and cultural identity. The so called "New Urbanism" carefully considers these physical conditions and claims these should be re-proposed for contemporary settlements [60]. The image of the centre as a pleasant place is so anchored that even some shopping malls adopt the forms and dimensions of the traditional open-air historic centre. 


\subsection{Recurrent Re-generation and Accumulation of Resources or Embedded Energy}

The large majority of the built stock in the city centre was built to last, has resisted centuries and was recurrently transformed or adapted to new inhabitants, requests or functions. The high quality of the structures, as well as of some ancient urban tissue, has allowed regeneration and renovation; the Italian Aldo Rossi and Giancarlo De Carlo clearly highlighted these historical and architectural processes and opportunities, well before the idea of sustainable recycling [61-63].

In the old towns, the economy has been circular for the traditionally limited resources and for the great value of the buildings and their location, long-term resilient practices were constantly adopted over the centuries for preserving the assets. Open public spaces were constantly improved and maintained for the community gathering for market, justice, religious events.

Conditions are radically changed and nowadays, possibilities are not considered limited anymore, but the money and energy embedded in the historical structures must be recognized and valued, as well as the regeneration opportunity, to neglect this potentiality when the world is praising recycling and circularity would be a waste [64].

\subsection{Vanished Appeal}

If, over the centuries, the centre was the preferred and most prestigious location for inhabitants and institutions and the distinction between the centre and periphery was sharp, today the trend has changed. The paradoxes lay in the fact that universally recognized positive characteristics do not impact the choices of inhabitants and institutions today. Even though everyone recognizes the centre's great beauty, even if high-density settlements are praised as one of the best solutions for a sustainable urban environment, even though the surviving community spirit allowed by the centre's spatial peculiarities is considered an antidote against the metropolisation, the past appreciation has vanished and the historic centre is not appealing.

The paper suggests this lost social and economic attractiveness is due to the structural mutations in Italian society and economics, not only since the economic crisis in 2008 but progressively since the 1990s, expressed in urban terms by the phenomena of sprawl [65]. In times of climate change, of circular economy and search for a new ecological balance, where the urban world is a major actor, laws and regulations which govern the urban heritage should face the contradictions the paradoxes pose and be questioned. The research suggests it is urgent politicians and city officials give a different value to the historic city centre; this topic has long been neglected and it is high time the battle for preservation is followed by another battle for the recycling of a stock of primary cultural, economic and social value.

\section{Conclusion: A Renewed Cultural and Economic Approach to Recycle the Wasted Urban Heritage for a Sustainable Development}

The analyzed city plans clearly show that the challenge of connecting built urban heritage and sustainability is nowadays in Italy not to protect heritage as material facts-a goal already achieved thanks to a rich history of theories and actions-but to safeguard its socio-economic vitality. The failure is due not only to the mega-trends of globalization which re-structure the geography of urban hierarchy but also to the inadequacy of planning tools conceived for different socio-economic conditions.

The city plans show also that the regulation system finds it difficult to adapt to the unforeseeable and generally fast urban dynamics and to renewed cultural and economic conditions. The link between the built urban heritage and sustainability is often claimed in theory, but not taken to the operational level: The empty inner cores are not considered opportunities to reduce land consumption and recycle valuable assets.

In the Italian cultural and economic contemporary context -stagnation particularly affected the small-to-medium-sized cities since 2008- a new set of policies have to be framed together with new planning processes. A renewed cultural and economic approach must also be adopted. This task must 
be accomplished in the general frame defined by the guidelines of the international institutions for conservation and heritage but with operational details suitable for the developed Countries [66,67].

The new goals of the city plans should be to:

- $\quad$ survey in depth the phenomenon of abandonment and acknowledge its impact; consider the built stock in the historic centre as an essential asset to balance expansion and re-functionalize the built heritage resources;

- re-define what changes of the heritage can be allowed without diminishing its value; in doing so, the plan must consider if the dense regulatory mechanism, matured over the course of decades of economic and demographic growth, is an obstacle for innovative practices and what elements in the policies prevent revitalization;

- find a balance between "original" residents and the significant presence of foreign people;

- contrast mono-functionality connected to the development of specific services, tourism in particular, in order to rely not only on one source of revenues and maintain residents and vitality.

The future phase of the research will consider cases were the decline of the city centre has been successfully dealt with in Italy and in Europe; this research will not only consider spatial planning documents but how these are part of integrated policies: In fact, the city plan alone cannot solve socio-economic issues. For this goal, the financial mechanisms and fiscal incentives for promoting the conservation of the historic centres and, at the same time, maintaining the inhabitants and the activities in the historic centre will be investigated $[68,69]$.

Author Contributions: Conceptualization, P.P., E.M.; methodology, P.P., E.M.; resources, P.P.; data curation, P.P.; writing—original draft preparation, P.P.; writing—review and editing, P.P., E.M.

Funding: This research received no external funding.

Conflicts of Interest: The authors declare no conflict of interest.

\section{References}

1. ANCSA Associazione nazionale centri storici artistici. Salvaguardia e risanamento dei centri storico-artistici, Atti del convegno nazionale per la Salvaguardia e il Risanamento dei Centri Storici; ANCSA: Gubbio, Italy, 1960.

2. Tafuri, M. Il problema dei centri storici nella nuova dimensione urbana. In La città territorio, un esperimento didattico sul centro direzionale di Centocelle in Roma; AAVV; Leonardo da Vinci: Roma, Italy, 1964; pp. 38-40.

3. Carozzi, C.; Rozzi, R. Centri storici, questione aperta: il caso delle Marche; De Donato: Bari, Italy, 1971.

4. AAVV. L'intervento pubblico nei centri storici, problemi sociali, giuridici, economici, architettonici e tecnici; Edizioni di Edilizia Popolare: Roma, Italy, 1973.

5. Vassallo, E. Centri antichi 1861-1974: note sull'evoluzione del dibattito. Restauro 1975, 19, 3-96.

6. Ceccarelli, P.; Indovina, F. Risanamento e speculazione nei centri storici; Angeli: Milano, Italy, 1977.

7. Ciardini, F.; Falini, P. L'analisi dei centri storici, manuale per la formazione degli strumenti di intervento urbanistico; Officina: Roma, Italy, 1981.

8. Per una storia del restauro urbano: Piani, strumenti e progetti per i centri storici; Giambruno, M. (Ed.) Cittastudi: Torino, Italy, 2007.

9. La scoperta della città antica. Esperienza e conoscenza del centro storico nell'Europa del Novecento; Cutolo, D.; Pace, S. (Eds.) Quodlibet Studio: Macerata, Italy, 2016.

10. ANCSA Associazione nazionale centri storici artistici; Cresme. Centri storici e futuro del Paese. Indagine nazionale sulla situazione dei centri storici; Documenti ANCSA: Roma, Italy, 2017.

11. Balletti, F.; Ghersi, A. Abitare il centro storico: studi documenti e progetti per il cuore della città di Genova; Alinea: Firenze, Italy, 2014.

12. Marcoaldi, P. Per la città di Viterbo: Masterplan del centro storico; Quodlibet: Macerata, Italy, 2018.

13. Bellia, P.; Puma, P. Firenze, la trasformazione del centro antico; Edifir: Firenze, Italy, 2018.

14. Ferrigni, F.; Sorrentino, M.C. Il futuro dei territori antichi: problemi, prospettive e questioni di governance dei paesaggi culturali evolutivi viventi; Edipuglia: Bari, Italy, 2013. 
15. Micelli, E.; Pellegrini, P. Wasting heritage. The slow abandonment of the Italian Historic Centres. J. Cult. Herit. 2018, 31, 180-188. [CrossRef]

16. Micelli, E.; Pellegrini, P. Vuoto al centro. Impiego ed abbandono del patrimonio dei centri antichi italiani. Territorio 2017, 82, 157-170. [CrossRef]

17. Habitat-III. Third United Nations Conference on Housing and Sustainable Urban Development; New Urban Agenda, UN: Quito, Ecuador, 2016.

18. United Nations. Transforming our World: The 2030 Agenda for Sustainable Development; UN: New York, NY, USA, 2015.

19. Labadi, S.; Logan, W. Urban Heritage, Development and Sustainability; Routledge: Oxford, UK, 2016.

20. Klusáková, L. Small Towns in Europe in the 20th and 21st Centuries: Heritage and Development Strategies; Karolinum Press: Prague, Czech Republic, 2018.

21. Management of Historic Centres; (Conservation of the European Built Heritage Series Book 2); Pickard, R. (Ed.) Taylor \& Francis, e-book: Oxfordshire, UK, 2013.

22. Free Market, the Irish Pavilion at the 16th International Architecture Exhibition Freespace 2018. Available online: http://free-market.ie/ (accessed on 10 July 2018).

23. Ministère de la Cohésion des territoires et des Relations avec les collectivités territoriales. Action Coeur de Ville. Available online: https://www.cget.gouv.fr/sites/cget.gouv.fr/files/atoms/files/plaquette_actioncoeurdeville. pdf (accessed on 10 March 2019).

24. Nilsson, L. Can small towns survive in a global World? In Proceedings of the International Conference EAUH 2018 Urban Renewal and Resilience, Cities in Comparative Perspective, Rome, Italy, 28 August-1 September 2018.

25. Statistiche ISTAT. Censimento Popolazione Abitazioni. Available online: http://dati-censimentopopolazione. istat.it/Index.aspx (accessed on 10 May 2018).

26. Statistiche ISTAT. Censimento Industria e servizi. Available online: https://www.istat.it/it/censimentipermanenti/censimenti-precedenti/industria-e-servizi (accessed on 10 May 2018).

27. ISTAT-Istituto nazionale di statistica. Forme, Livelli e Dinamiche Dell'urbanizzazione In Italia; ISTAT: Roma, Italy, 2017.

28. Comune di Treviso. Piano di Assetto del Territorio Comunale (P.A.T.). Available online: http://www.comune. treviso.it/pat/ (accessed on 10 September 2018).

29. Comune di Treviso. Piano degli Interventi (P.I.). Available online: https://www.comune.treviso. it/rigenerazione-urbana-riqualificazione-quartieri-4/urbanistica/piano-degli-interventi-p-i/ (accessed on 10 September 2018).

30. Comune di Treviso. PAT, R03, Verifica del Dimensionamento; Comune di Treviso: Treviso, Italy, 2015.

31. Comune di Treviso. PAT, R01, Relazione tecnica; Comune di Treviso: Treviso, Italy, 2015.

32. Comune di Treviso. PI, R01, Relazione tecnica illustrative; Comune di Treviso: Treviso, Italy, 2018.

33. Comune di Treviso. PI, R02, Verifica del Dimensionamento; Comune di Treviso: Treviso, Italy, 2018.

34. Comune di Udine. Piano Regolatore Comunale Generale. Available online: http://www.comune. udine.gov.it/aree-tematiche/edilizia-territorio/urbanistica/piano-regolatore-generale-comunale (accessed on 15 September 2018).

35. Comune di Udine. PRGC, Relazione Generale; Comune di Udine: Udine, Italy, 2012.

36. Comune di Udine. PRGC, Relazione sul dimensionamento; Comune di Udine: Udine, Italy, 2012.

37. Comune di Modena. PRG—Piano Regolatore Generale. Available online: http://urbanistica.comune.modena. it/ (accessed on 18 September 2018).

38. Comune di Modena. Rapporto sul centro storico. Available online: http://urbanistica.comune.modena.it/ index_Centro.html (accessed on 18 September 2018).

39. Comune di Modena. PRG 2003, Testo coordinato delle norme di PSC_POC—RUE; Comune di Modena: Modena, Italy, 2015.

40. Comune di Modena. PRG 2003, Carta di PSC del Centro Storico, 2.t1, Variante al POC-RUE approvata con delibera di C.C. $n^{\circ} 48$ del 07/05/2015; Comune di Modena: Modena, Italy, 2015.

41. Comune di Vicenza. Piano regolatore comunale (Pat-Pi) e piani urbanistici (Pua). Available online: https://www.comune.vicenza.it/servizi/prg.php (accessed on 20 September 2018).

42. Comune di Vicenza. PAT Relazione Tecnica; Comune di Vicenza: Vicenza, Italy, 2010. 
43. Comune di Vicenza. Relazione al piano particolareggiato di esecuzione del centro storico; Comune di Vicenza: Vicenza, Italy, 1969.

44. Comune di Vicenza. PI, Relazione Programmatica; Comune di Vicenza: Vicenza, Italy, 2013.

45. Pellegrini, P.; Micelli, E. Wasted heritage. Between policies for urban heritage and land consumption. In Proceedings of the 6th International Conference on Heritage and Sustainable Development HERITAGE 2018, Granada, Spain, 15 June 2018.

46. Cristinelli, G. Saverio Muratori e Egle Renata Trincanato. La nascita del restauro urbano in Italia; Ginevra Bentivoglio EditoriA: Roma, Italy, 2013.

47. Il progetto del passato; Pedretti, B. (Ed.) Bruno Mondadori: Milano, Italy, 1997.

48. Koolhaas, R. Preservation Is Overtaking Us; Carver, J., Ed.; Columbia Books on Architecture and the City, GSAPP Transcripts: New York, NY, USA, 2014.

49. Romano, M. La città come opera d'arte; Einaudi: Milano, Italy, 2008.

50. Ferlenga, A.; Vassallo, E. Antico e Nuovo. Architetture ed Architettura; Il Poligrafo: Venezia, Italy, 2008.

51. Cervellati, P. L'arte di curare la città; Il Mulino: Bologna, Italy, 2000.

52. Rogers, R. Cities for a Small Planet; Basic Books: London, UK, 1998.

53. Glaeser, E. Triumph of the City; Penguin Random House: New York, NY, USA, 2011.

54. Owen, D. Green Metropolis. Why Living Smaller, Living Closer, and Driving Less Are the Keys to Sustainability; Riverhead Books: New York, NY, USA, 2009.

55. Ng, E. Designing High-Density Cities: For Social and Environmental Sustainability; Earthscan Ltd.: London, UK, 2010.

56. Barattucci, C. La riqualificazione sostenibile dei centri storici come risposta italiana alla moltiplicazione degli ecoquartieri europei. Presented at the XXI Conferenza Nazionale Societa' Italiana degli Urbanisti, Firenze, Italy, 5 June 2018.

57. Sitte, C. The Art of Building Cities: City Building According to Its Artistic Fundamentals; Martino Fine Books: Eastford, CT, USA, 2013.

58. Whyte, W. The Social Life of Small Urban Spaces; Project for Public Spaces: New York, NY, USA, 1980.

59. Gehl, J. Life between Buildings: Using Public Space; Island Press: Washington, DC, USA, 1987.

60. Congress for the New Urbanism. Charter of the New Urbanism; McGraw-Hill Professional: San Francisco, CA, USA, 1999.

61. Rossi, A. L'architettura della città; Marsilio: Padova, Italy, 1966.

62. De Carlo, G. Urbino: la storia di una città e il piano della sua evoluzione urbanistica; Marsilio: Padova, Italy, 1966.

63. Re-cycle Italy. Available online: http://www.recycleitaly.net (accessed on 5 June 2018).

64. Ellen Macarthur Foundation. Available online: ellenmacarthurfoundation.org (accessed on 5 June 2018).

65. Indovina, F. La città diffusa. In La città diffusa; Indovina, F., Matassoni, F., Savino, M., Sernini, M., Torres, M., Vettoretto, L., Eds.; Daest-IUAV: Venezia, Italy, 1990; pp. 21-43.

66. Bandarin, F.; van Oers, R. Il paesaggio urbano storico: La gestione del patrimonio in un secolo urbano; CEDAM: Padova, Italy, 2014; pp. 32-33.

67. Operationalising the Historic Landscape, a Practitioner's View; Zhou, J.; van Oers, R. (Eds.) Tongji University Press: Shanghai, China, 2018.

68. Forte, F. Historic, Artistic and Cultural Patrimony for a "Habitable City": Incentives for Care. In Integrated Evaluation for the Management of Contemporary Cities, SIEV 2016; Mondini, G., Fattinnanzi, E., Oppio, A., Bottero, M., Stanghellini, S., Eds.; Springer: Cham, Switzerland, 2018; pp. 233-243. [CrossRef]

69. Pickerill, T.; Pickard, R. A Review of Fiscal Measures to Benefit Heritage Conservation; RICS Research Paper Series; Dublin Institute of Technology: Dublin, Ireland, 2007; Volume 7, p. 6.

(C) 2019 by the authors. Licensee MDPI, Basel, Switzerland. This article is an open access article distributed under the terms and conditions of the Creative Commons Attribution (CC BY) license (http://creativecommons.org/licenses/by/4.0/). 